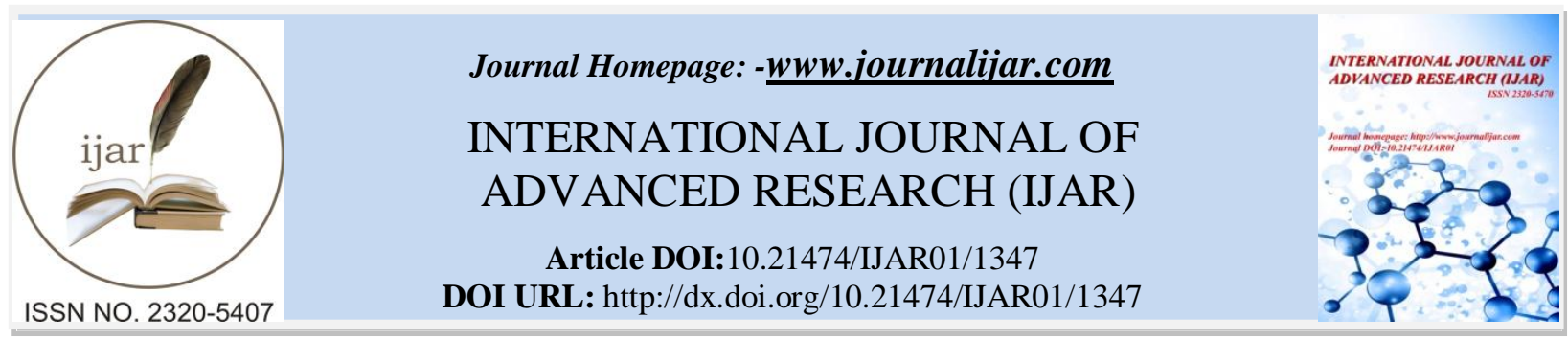

RESEARCH ARTICLE

\title{
INVESTORS' PERCEPTION TOWARDS EQUITY DERIVATIVES WITH SPECIAL REFERENCE TO ANANTAPURAMU DISTRICT.
}

\begin{abstract}
Dr. U. Raghavendra Prasad.
Assistant Professor, Department of Management Studies, Madanapalle Institute of Technology \& Science (UGCAutonomous),Madanapalle-517325, (A P) India.
\end{abstract}

\section{Manuscript Info}

Manuscript History

Received: 11 June 2016

Final Accepted: 19 July 2016

Published: August 2016

Key words:-

Equity Derivatives, Futures, Investor,

Options, Risk

\section{Abstract}

Equity derivative is a class of derivatives whose value is at least partly derived from one or more underlying equity securities. Options and futures are by far the most common equity derivatives. Futures are standardized contracts between two parties to buy or sell an asset (underlying) at a certain time in the future for a certain price. An option is a contract that gives the buyer the right, to buy or sell the underlying at a stated date and at a specific price. A call option gives the right to buy and a put option gives the right to sell. This paper aims to measure the investors' perception towards Equity Derivatives.

Copy Right, IJAR, 2016,. All rights reserved.

\section{Introduction:-}

A derivative is a financial instrument, which derives its value from some other financial price. This "other financial price" is called the underlying. For example, in the case of Nifty futures, Nifty index is the underlying. Futures are standardized contracts between two parties to buy or sell an asset (underlying) at a certain time in the future for a certain price.Futures trading provides transparency, liquidity, anonymity of trades, and also eliminates the counter party risks due to the guarantee provided by National Securities Clearing Corporation Limited. An option is a contract that gives the buyer the right, to buy or sell the underlying at a stated date and at a specific price. A call option gives the right to buy and a put option gives the right to sell.This paper aims to measure investors' perception towards risk, participation and derivative products in equity derivatives.

\section{Participants in the Derivatives Markets:-}

The derivatives market is similar to any other financial market and has following three broad categories of participants:

Hedgers:- These are investors with a present or anticipated exposure to the underlying asset which is subject to price risks. Hedgers use the derivatives markets primarily for price risk management of assets and portfolios.

Speculators:- These are individuals who take a view on the futuredirection of the markets. They take a view whether prices would rise orfall in future and accordingly buy or sell futures and options to try andmake a profit from the future price movements of the underlyingasset.

Corresponding Author:-Raghavendra Prasad. 
Arbitrageurs:- They take positions in financial markets to earnriskless profits. The arbitrageurs take short and long positions in thesame or different contracts at the same time to create a position whichcan generate a riskless profit.

\section{Review of literature:-}

Sarathkumar, K., \&Dhandhayuthapani, S. P. (2016). The attitude of investor's is changing towards derivative market in India for the last some years and with the introduction of behavioral finance the researcher would like to capture that. The concept of behavioral finance is growing in the capital market, there is hardly any place where its concepts aren't being applied.

Manrai, D. R. (2015). The crux of the study will give the researcher a quantitative model reflecting the factors affecting the investor behavior in derivative market with load factors. Through this study the researchers would like to study the various factors responsible for the investment behavior in derivative market.

RAKESH, H.M. (2015). Study Intends to find preference level of investors on various Capital Market instruments, to find out the type of risk which are considered by the investors, to find out the ways through which the investors on various minimizes their risk and lastly to find out the preferences of Investors in derivatives market.

Pallavi, E. V. P. A. S., \& Raju, T. K. (2014). The derivatives market is witnessing tremendous growth in India. The statistical data reveals that the total turnover of futures and options in NSE market are Rs 67510.02 billion and Rs 247820.01 billion respectively by 2012-13. The retail and institutional investors occupied a key role in development of derivatives trading in India.

Tripathi, G. (2014). Conducted a survey through structured questionnaire targeting 100 retail investors of Delhi/NCR region to understand the awareness and attractiveness of different derivative securities amongst the retail investors.

Pasha, S. A. M. (2013). An attempt is made by the researcher to know what kind of perceptions had by retail investors in India based on Andhra Pradesh State reference with a sample size of 500 respondents by using simple percentage bar diagrams. Ultimately, financial derivatives should be considered part of any investor's riskmanagement strategy to ensure that value - enhancing investment opportunities are pursued.

Savitha, R., \&Deepika, S. R. (2013). This research is an attempt to find the efficiency of the sentimental indicators of financial derivatives in predicting the trend of the market (behaviour of NIFTY index). Participants in the stock markets believe that the amount of open interest (OI) in a particular contract has a bearing on the behavior of the price of the contract.

Kukreja, G. (2012). Aims to measure the investors' perception towards Indian capital market with reference to National Capital Region (NCR) investors of India. 120 samples are selected for this study. Major findings of this study include, age has significant impact on investment, and educational qualification has significant impact on tax advantages. 119 functional variables are used in this study to measure investors' perception.

Choksi, A. (2010). The most significant event in finance during the past decade has been the astonishing development and expansion of financial derivatives. These instruments enhance the ability to differentiate risk and allocate it to those investors who are most able and willing to take it-a process that has undoubtedly improved national productivity, growth and standards of living.

Ramanjaneyalu, N., \&Hosmani, A. P. (2010). Studied, derivatives occupy an important place as a risk reducing mechanism. Derivatives are useful for reducing many of the risks mentioned above. History of financial markets has evidence to suggest that when risk management avenues are provided by means of derivatives, markets attract higher volumes of investments from savers, strengthening the markets in the process.

Paraschiv, D., \&Raghavendra, S. (2009, March). Introduced a stock scanner evaluator for stocks and options. In the presented work the scanner picks from thousands of stocks the most suitable stocks for an options or stocks investor. The proposed stocks scanner evaluator suggests the stocks that have the largest positive near future change (for purchasing stocks or calls) and the stocks that have the largest negative near future change (for purchasing puts). 
Ravichandran, D. K. (2008) was undertaken to find out the awareness level of various capital market instruments and also to find out their risk preference in various segments.

Sandeep Srivastava, Surendra S Yadav, P K Jain September (2008). The authors conducted a survey of brokers in the recently introduced derivatives markets in India to examine the brokers' assessment of market activity and their perception of the benefits and costs of derivative trading.

\section{Objectives of the study:-}

1. To analyze investors' perception towards stock market.

2. To analyzeinvestors'preference of the equity derivatives product and their participation in Equity Derivatives.

\section{Methodology for research:-}

The research design is analytical in nature. The study is based on primary and secondary data. The primary data is collected through structured Questionnaire. Secondary data was gathered from books, journals and websites like SEBI, BSE and NSE etc., for review of literature. Convenience sampling method is used for this study. The sample size covered 100 investors belonging to Anantapuramu district in Andhra Pradesh.Statistical tools like MannWhitney $\mathrm{U}$ andKruskal-Wallis $\mathrm{H}$ test were used for analysing data. The study was conducted during the period in June and July 2016.

\section{Limitations of the study:-}

Only 100 investors have been considered for this study. Hence, it cannot be generalized for the entire active market participants in the equity derivatives. The geographical area of this study is confined to Anantapuramu district only.

\section{Hypotheses of the Study:-}

In line with the objectives of the study, the following hypotheses have been framed and tested.

1. H0: Index options preference doesn't differ with gender of investors'.

2. H0: Index options preference doesn't differ with age of investors'.

3. H0: Index options preference doesn't differ with income of investors'.

\section{DataAnalysis and Interpretation:-}

Table 1:-Descriptive statistics.

\begin{tabular}{|c|c|c|}
\hline Variables & Category & No. of Respondents \\
\hline \multirow{2}{*}{ Gender } & Male & 82 \\
\hline & Female & 18 \\
\hline \multirow[t]{4}{*}{ Age } & Less Than 25 & 11 \\
\hline & Between 25 to 40 & 45 \\
\hline & Between 41 to 50 & 24 \\
\hline & More than 50 & 20 \\
\hline \multirow[t]{2}{*}{ Qualification } & Below Graduation & 33 \\
\hline & Graduation and Above & 67 \\
\hline \multirow[t]{5}{*}{ Occupation } & Agriculture & 6 \\
\hline & Private Sector Service & 39 \\
\hline & Public Sector (Government Services) & 17 \\
\hline & Business & 31 \\
\hline & $\begin{array}{l}\text { Others (Professional, Retired, Housewives, } \\
\text { Students, Etc.,) }\end{array}$ & 7 \\
\hline \multirow{4}{*}{$\begin{array}{l}\text { Average income } \\
\text { per annum }\end{array}$} & Less than 2.5 lakhs & 34 \\
\hline & 2,50,000 lakhs-5 lakhs & 39 \\
\hline & $5,00,001-10$ lakhs & 18 \\
\hline & Above 10 lakhs & 9 \\
\hline
\end{tabular}

Source: Primary Data.

The sample size chosen for the study was 100 investors from Anantapuramu district. Table 1, shows that eighty two of the total samples are males and eighteen percent are females. Forty five sample size have age between 25 years to 40 years, followed by twenty four percent of total sample have age between 41 to 50 . Sixty seven percent of the total respondents are having qualification of Graduation and above and thirty three percent of respondents are 
having educational qualification of less than graduation. Thirty nine percent, average income of the investor range between 2.5 lakh to 5 lakh followed by thirty four percent less than 2.5 lakh

Table 2:-Frequency of trading.

\begin{tabular}{|c|c|}
\hline Particulars & Respondents \\
\hline Daily & 11 \\
\hline Weekly & 22 \\
\hline Monthly & 37 \\
\hline Occasionally & 30 \\
\hline
\end{tabular}

Source: Primary Data.

Thirty seven percent investors trade in equity derivatives, monthly followed by thirty percent trade in equity derivatives occasionally.

Table 3:-Source of information for decision making

\begin{tabular}{|c|c|}
\hline Particulars & Respondents \\
\hline Print Media & 25 \\
\hline Electronic Media & 21 \\
\hline Brokers & 27 \\
\hline Self & 17 \\
\hline Actions of Others & 10 \\
\hline
\end{tabular}

Source: Primary Data.

Table 3, shows that 27 percent of the total sample takes cues from brokers for their investing decisions, twenty five percent takes from print media, twenty one percent take cues from electronic media, self and actions of others take seventeen percent and ten percent respectively.

Table 4:- Method of analysis for decision making.

\begin{tabular}{|c|c|}
\hline Particulars & Respondents \\
\hline Fundamental analysis & 27 \\
\hline Technical analysis & 20 \\
\hline Both & 53 \\
\hline
\end{tabular}

Source: Primary Data.

More than half of the investors follow both fundamental analysis and technical analysis for decision making to invest in the market. Twenty seven percent investors follow fundamental analysis and twenty percent investors follow technical analysis.

Table 5:-Opinion at present market.

\begin{tabular}{|c|c|}
\hline Particulars & Respondents \\
\hline Bullish & 65 \\
\hline Bearish & 19 \\
\hline No idea & 16 \\
\hline
\end{tabular}

Source: Primary Data.

Sixty five percent investors bullish about Indian market, nineteen percent bearish and sixteen percent no idea about the market.

Table 6:-Risk profile of the investor.

\begin{tabular}{|c|c|}
\hline Particulars & Respondents \\
\hline Low risk & 52 \\
\hline Medium risk & 33 \\
\hline High risk & 15 \\
\hline
\end{tabular}

Source: Primary Data.

More than half of the investors are taking low risk in the market. Thirty three percent investors are taking medium risk followed by high risk fifteen percent. 
Table 7:-Participation in the equity derivatives segment.

\begin{tabular}{|c|c|}
\hline Particulars & Respondents \\
\hline Hedging & 22 \\
\hline Speculation & 52 \\
\hline Arbitrage & 26 \\
\hline
\end{tabular}

Source: Primary Data.

More than half of the investors' participation in derivatives segment as speculators. Twenty six percent are trading as arbitrageurs and twenty two percent are using derivatives products are hedging purpose.

Table 08: Investors' Preference of the derivatives product trading (ranking)

\begin{tabular}{|c|c|c|}
\hline Product & Mean & Rank \\
\hline Index Futures & 3.54 & 4 \\
\hline Stock Futures & 2.06 & 2 \\
\hline Index Options & 1.36 & 1 \\
\hline Stock Options & 3.04 & 3 \\
\hline
\end{tabular}

Source: Primary data

Investors first preference of the tradingin equity derivatives is index options (mean $=1.36)$, followed by stock futures $($ mean $=2.06)$, Stock options $($ mean $=3.04)$ and Index futures $($ mean $=3.54)$.

\section{Index Options Preference:-}

Among the derivative products, investors prefer index options as their first preference (1.36). Further, hypotheses were tested with demographic profiles of investors in terms of gender, age and income.

Table 09:-Mann-Whitney Test.

\begin{tabular}{|l|l|l|l|l|}
\hline Ranks & Gender & $\mathrm{N}$ & Mean Rank & Sum of Ranks \\
\hline \multirow{3}{*}{ Index Options } & Male & 82 & 51.28 & 4205.00 \\
\cline { 2 - 5 } & female & 18 & 46.94 & 845.00 \\
\cline { 2 - 4 } & Total & 100 & & \\
\hline Test Statistics & Index Options \\
\hline & 674.000 \\
\hline Mann-Whitney U & 845.000 \\
\hline Wilcoxon W & -.718 & \\
\hline Z & .473 \\
\hline Asymp. Sig. (2-tailed) & \\
\hline a. Grouping Variable: Gender &
\end{tabular}

Inference:Man Whitney $\mathrm{U}$ test was performed for determining the differences between male and female preferences for index options. The mean ranks of male and female are 51.28 and 46.94 respectively. The Asymp. Sig. value is .473 which is more than .05 of probability value hence we need to accept the null hypothesis. Therefore, Index options preference doesn't differ with investors' gender.

Table 10:-Kruskal Wallis Test.

\begin{tabular}{|l|l|l|l|}
\hline Ranks & Age & N & Mean Rank \\
\hline \multirow{3}{*}{ Index Options } & Below 25 & 11 & 50.05 \\
\cline { 2 - 4 } & Between 25 to 40 & 45 & 48.66 \\
\cline { 2 - 4 } & Between 41 to 50 & 24 & 56.67 \\
\cline { 2 - 4 } & More than 50 & 20 & 47.50 \\
\cline { 2 - 3 } & Total & 100 & \\
\hline \multicolumn{5}{|l|}{} \\
\hline \multicolumn{2}{|l|}{} \\
\hline Chi-Square & Index Options \\
\hline Df & 2.319 & \\
\hline
\end{tabular}


\begin{tabular}{|l|l}
\hline Asymp. Sig. & .509
\end{tabular}

a. Kruskal Wallis Test

b. Grouping Variable: Age

Inference:Kruskal Wallis Test was performed for determining investors' index preferences with age. The mean ranks of age below 25 is 50.05, between, 25-40 is 48.66,between, 41-50 is 56.67 and above 50 is 47.50 . The Asymp. Sig.value is .509 which is more than .05 of probability value hence we need to accept the null hypothesis. Therefore, Index options preference doesn't differ with investors' age.

Table 11:-Kruskal Wallis Test.

\begin{tabular}{|c|c|c|c|c|}
\hline \multicolumn{5}{|l|}{ Ranks } \\
\hline & \multicolumn{2}{|l|}{ Income } & $\mathrm{N}$ & Mean Rank \\
\hline \multirow{5}{*}{ Index Options } & \multicolumn{2}{|l|}{ Less than 2.5 lakhs } & 34 & 50.44 \\
\hline & \multicolumn{2}{|l|}{ 2,50,000-5 lakhs } & 39 & 48.22 \\
\hline & \multicolumn{2}{|l|}{ 5,00,001-10 lakhs } & 18 & 54.17 \\
\hline & \multicolumn{2}{|l|}{ Above 10 lakhs } & 9 & 53.28 \\
\hline & \multicolumn{2}{|l|}{ Total } & 100 & \\
\hline \multicolumn{5}{|c|}{ Test Statistics $^{\mathbf{a}, \mathbf{b}}$} \\
\hline \multirow{2}{*}{\multicolumn{2}{|c|}{ Chi-Square }} & \multicolumn{3}{|c|}{ Index Options } \\
\hline & & \multicolumn{3}{|c|}{.956} \\
\hline \multicolumn{2}{|l|}{ Df } & \multicolumn{3}{|l|}{3} \\
\hline \multicolumn{2}{|l|}{ Asymp. Sig. } & .812 & & \\
\hline \multicolumn{5}{|c|}{ a. Kruskal Wallis Test } \\
\hline \multicolumn{5}{|c|}{ b. Grouping Variable: Income } \\
\hline
\end{tabular}

Inference:Kruskal Wallis Test was performed for determining investors' index preferences with income. The mean ranks of income below 2.5 lakh is 50.44, 2.5lakh-5 lakhs is 48.22, 5, 00,001-10 lakhs is 54.17 and Above 10 lakhs 53.28. The Asymp. Sig.value is .812 which is more than .05 of probability value hence we need to accept the null hypothesis. Therefore, Index options preference doesn't differ with investors' income.

\section{Conclusion:-}

Risk is a key element of investment. Index options preference doesn't differ with age, gender and income of investors'. Investors' first preference in derivatives product is index options followed by stock futures,stock options and index futures. Most of the investors are trading in derivatives market, monthly followed by occasionally. Majority of the investors are participating as speculators in equity derivatives.

\section{References:-}

1. Bezzina, F. H., \&Grima, S. (2012). Exploring factors affecting the proper use of derivatives: an empirical study with active users and controllers of derivatives. Managerial Finance, 38(4), 414-435.

2. Choksi, A. (2010). Derivative Trading in Indian Stock Market: Investor's Perception. Indian Journal of Finance, 4(3), 50-58.

3. Ganeson, P., Rengamani, K. T., \&Kiruthiga, P. (2004). Perceptions of, and influences on, derivatives investments: A study of Indian investors. Journal of Derivatives \& Hedge Funds, 9(4), 365.

4. Hoffmann, A. O., Post, T., \&Pennings, J. M. (2013). Individual investor perceptions and behavior during the financial crisis. Journal of Banking \& Finance, 37(1), 60-74.

5. Hull, J. C. (2006). Options, futures, and other derivatives. Pearson Education India.

6. Koonce, L., Lipe, M. G., \&McAnally, M. L. (2008). Investor reactions to derivative use and outcomes. Review of Accounting studies, 13(4), 571-597.

7. Kothiwal, R., \&Goel, A. (2012). Review of trading/marketing strategies of futures and options in India. Asian Journal of Research in Social Sciences and Humanities, 2(4), 138-139.

8. Kukreja, G. (2012). Investors' Perception for Stock Market: Evidences from National Capital Region of India. Interdisciplinary journal of contemporary research in business, 4(8), 712-726.

9. Manrai, D. R. (2015). Investor Behaviour towards Derivative Markets in Indian Context. IOSR Journal of Business and Management (IOSR-JBM), 10-14. 
10. Pallavi, E. V. P. A. S., \& Raju, T. K. (2014). AN EMPIRICAL ANALYSIS ON PERCEPTION OF RETAIL INVESTORS TOWARDS DERIVATIVES MARKET WITH REFERENCE TO VISAKHAPATNAM DISTRICT. Indian Journal of Management Science, 4(1), 54.

11. Pasha, S. A. M. (2013). RETAIL INVESTORS'PERCPTION ON FINANCIAL DERIVATIVES IN INDIA. European Scientific Journal, 9(22).

12. RAKESH, H. (2015). INVESTORS'PREFERENCE TOWARDS INVESTMENT AVENUES IN CAPITAL MARKET: A STUDY WITH REFERENCE TO DERIVATIVES. International Journal of Marketing, Financial Services and Management Research, 3(9).

13. Ramanjaneyalu, N., \&Hosmani, A. P. (2010). Financial Derivatives and Risk Management: Retail Investors' View. Indian Journal of Finance, 4(10), 17-29.

14. Ravichandran, K. (2008). A study on Investors Preferences towards various investment avenues in Capital Market with special reference to Derivatives.Journal of Contemporary Research in Management, 3(3).

15. Ricciardi, V. (2004). A risk perception primer: A narrative research review of the risk perception literature in behavioral accounting and behavioralfinance.Available at SSRN 566802.

16. Sachithanantham, V., Jaffer, M. S., Raja, J., \& Kumar, A. S. (2007). Investors' perception towards capital market reforms in India. SMART Journal of Business Management Studies, 3(1), 39-45.

17. Sarathkumar, K., \&Dhandhayuthapani, S. P. (2016). Analytical Study on Indian Derivatives Market With Reference to Investors' Attitude. International Journal for Innovative Research in Science and Technology, 2(11), 680-682.

18. Savitha, R., \&Deepika, S. R. (2013). An empirical study on the behaviour of nifty index by examining the derivative contract. Indian Journal of Finance, 7(6), 5-15.

19. Tripathi, G. (2014). An Empirical Investigation of Investors Perception towards Derivative Trading. Global Journal of Finance and Management, 6(2), 99-104.

20. Vignesh, K., \& Lawrence, A. D. R. A STUDY ON THE AWARENESS OF DERIVATIVES AMONG RETAIL INVESTORS IN TRICHY.

21. Paraschiv, D., \&Raghavendra, S. (2009, March). Stocks scanner evaluator for stocks or options. In 2009 IEEE Symposium on Computational Intelligence for Financial Engineering (pp. 28-35). IEEE.

www.nseindia.com

www.bseindia.com

www.sebi.gov.in 